Research article

\title{
Biogenic fabrication, characterization, and assessment of antibacterial activity of silver nanoparticles of a high altitude Himalayan lichen - Cladonia rangiferina (L.) Weber ex F.H. Wigg.
}

Himanshu Rai* and Rajan Kumar Gupta

Centre of Advanced Study in Botany, Institute of Science,

Banaras Hindu University, Varanasi-221005, Uttar Pradesh, India

*Corresponding Author: himanshurai08@yahoo.com

[Accepted: 12 August 2019]

\begin{abstract}
Silver nanoparticles synthesized using plant metabolites provide an edge over chemically synthesized compounds due to their comparatively efficient antimicrobial activity. In the present study, AgNPs was prepared by bioreduction of silver nitrate $\left(\mathrm{AgNO}_{3}\right)$ using the aqueous extract of Cladonia rangiferina collected $\geq 3500 \mathrm{~m}$ in Uttarkashi district of Uttarakhand, western Himalaya. The formation of Ag NPs was indicated by yellow-brown color after $72 \mathrm{~h}$. The AgNPs were characterized by UV-Vis spectrophotometry, Fourier transformed infrared (FTIR) spectroscopy, scanning electron spectroscopy (SEM) analysis. Ag-NPs thus obtained were tested for antimicrobial activity against selected gram-negative (i.e. Escherichia coli, Klebsiella pneuomoniae, and Pseudomonas aeruginosa) and gram-positive (i.e. Bacillus subtilis, Staphylococcus aureus, and Staphylococcus epidermidis) bacterial strains employing BauerKirby's disk diffusion assay using Gentamicin as positive control and distil water as negative control. The bioreduction of $\mathrm{AgNO}_{3}$ yielded stable spherical and rod-shaped Ag-NPs showing characteristic UV-Vis spectral band peak with specific color change. The FTIR showed the role of many functional groups of different organic lichen secondary metabolites in AgNPs fabrication and stabilization. The synthesized AgNPs showed enhanced activity to positive control (i.e. Gentamicin). The study highlighted that lichen AgNPs can be used as better antibacterial material.

Keywords: Bactericidal - Cladonia - Gram-negative - Himalaya - Silver nanoparticles.
\end{abstract}

[Cite as: Rai H \& Gupta RK (2019) Biogenic fabrication, characterization, and assessment of antibacterial activity of silver nanoparticles of a high altitude Himalayan lichen - Cladonia rangiferina (L.) Weber ex F.H. Wigg. Tropical Plant Research 6(2): 293-298]

\section{INTRODUCTION}

Nanoparticles are extensively used in optronics, textile industry, pharmacology, agriculture, environmental care, food processing, and as antimicrobial agents (Shekhawat et al. 2014, Roohizadeh et al. 2015, Hussain et al. 2015, Singh et al. 2017, Qayyum et al. 2019, Rodrigues et al. 2019, Yazdian-Robati et al. 2019, Tryfon et al. 2019, Singh \& Singh 2019, Alvarez-Ordóñez et al. 2019, Dixit \& Tripathi 2019). Among the various strategies of nanoparticle synthesis, the biogenic/ green synthesis of nanoparticles exploiting plant components or their extract in non-hazardous solvents (i.e. water) has emerged as an alternative approach, because of its easy methodology, cost-effectiveness, eco-friendliness and high-yields (Husen \& Siddiqi 2014, Husen 2017). In the majority of biogenic synthesis of phytonanoparticles, organisms such as bacteria, fungi, algae, and flowering plants have been utilized (Korbekandi et al. 2009, Yadav et al. 2015), very rarely lichens are used to synthesize nanoparticles (Siddiqi et al. 2018). Out of about 800 known lichen secondary metabolites, $80-85 \%$ are unique to them and are known to possess antibacterial, antiviral, antioxidant, anticancer and antigenotoxic activities (Elix \& Stocker-Wörgötter 2008, Ranković 2015).

Among the metal nanoparticles, silver nanoparticles are the most preferred nanoparticles (Mishra et al. 2019). The few reported studies on lichen/ lichen metabolite mediated fabrication of silver nanoparticles (AgNPs) have shown that lichens can be used for green synthesis of AgNPs which show antimicrobial activity 
against a broad spectrum of bacterial strains (Mie et al. 2012, Dasari et al. 2013, Y1ldiz et al. 2014).

The present study was carried out to fabricate the AgNPs from a terricolous lichen Cladonia rangiferina (L.) Weber ex F.H. Wigg. collected from alpine habitat $(\geq 3500 \mathrm{~m})$ of western Himalaya and assess the antibacterial properties of these AgNPs to bacterial strains.

\section{MATERIALS AND METHODS}

The lichen was collected adjacent to Morinda lake (N 31 09'57.5" E 80 25'39.48") from the average elevation of $3798 \mathrm{~m}$ in Govind wildlife sanctuary situated in Uttarkashi district of Uttarakhand in western Himalaya (Fig. 1). The compound lichens found growing on soil over flat rock bed were collected for the experiment. The terricolous lichen was collected in paper bags in field with frequent air drying during the transit from field to laboratory. The lichen sample was air-dried and curated according to standard procedure (Rai et al. 2014a). The lichen sample was identified and authenticated up to species level using standard lichenological procedure of morpho-anatomical study, chemical spot tests, TLC profiling with reference to relevant keys and monographs at the lichenology laboratory of the CSIR-National Botanical Research Institute, Lucknow, Uttar Pradesh, India (Rai et al. 2014b).
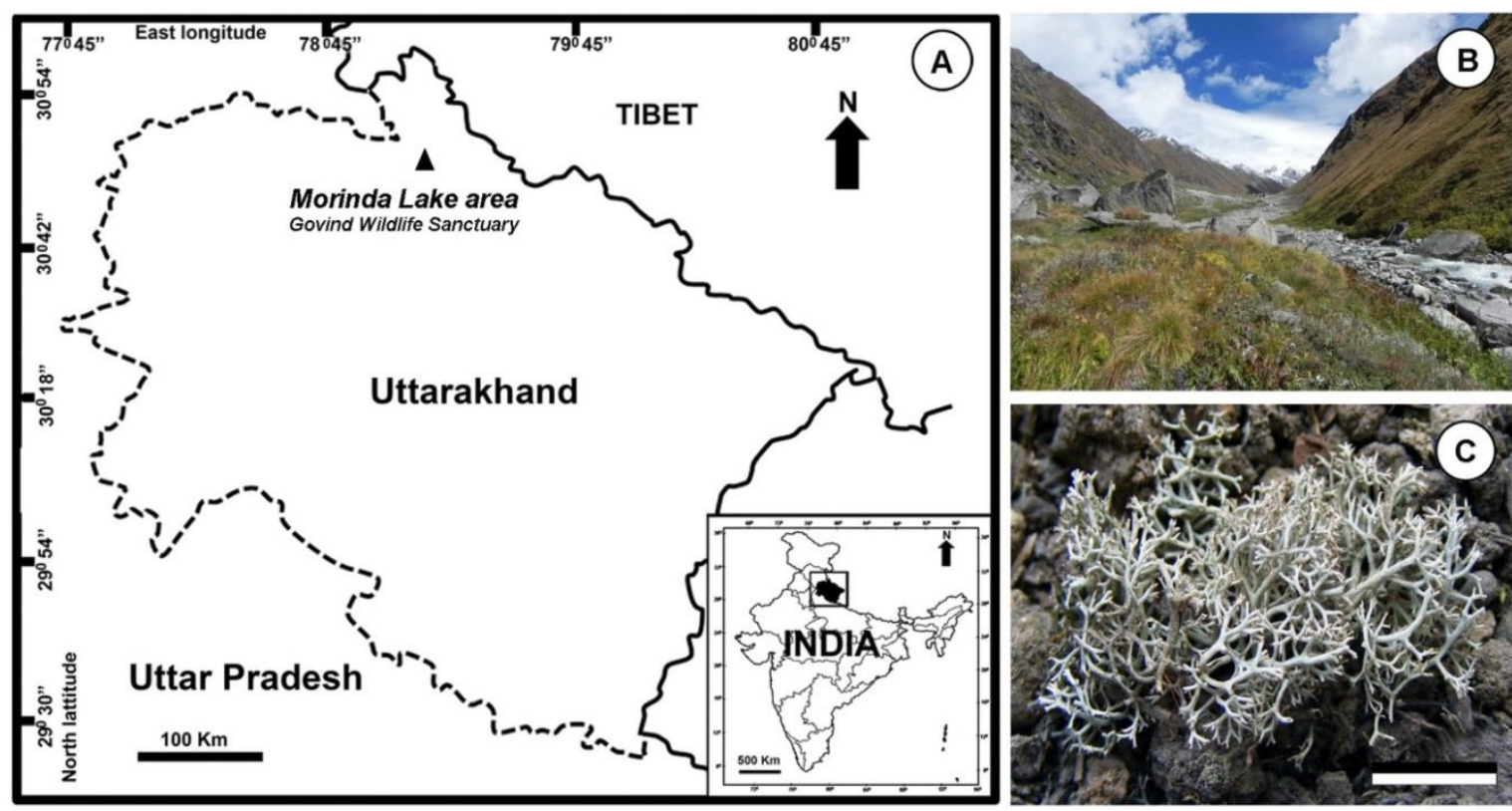

Figure 1. The site of lichen collection: A, The location map of the collection site; B, Morinda lake habitat; C, Cladonia rangiferina (L.) Weber ex F.H. Wigg. (LWG) habitus, (Scale $=2 \mathrm{~cm})$.

The aqueous extract of lichen was prepared by boiling about $3 \mathrm{~g}$ of air-dried coarsely grounded lichen thallus in $45 \mathrm{ml}$ of Mili-Q water at $80^{\circ} \mathrm{C}$ for $20 \mathrm{~min}$. The mixture war filter through Whatman No. 1 (pore size $125 \mathrm{~mm}$ ) to discard any thallus debris. The filtrate was stored at $4^{\circ} \mathrm{C}$ for further procedure. About $15 \mathrm{ml}$ of lichen aqueous extract was added into $45 \mathrm{ml}$ of $1 \mathrm{mM}$ silver nitrate solution (prepared in Mili-Q water). The mixture was alkalized by 2-3 drops of $0.1 \mathrm{M}$ sodium hydroxide and the solution mix was kept for $72 \mathrm{hrs}$ at room temperature $\left(25^{\circ} \mathrm{C}\right)$ to facilitate bioreduction of silver ions. The reduction of silver ions to AgNPs in aqueous extract was monitored by measuring the UV-Vis spectrum of solution using after diluting a small aliquot of the sample into distilled water in UV-Vis Spectrophotometer (Thermo Fisher 160 UV-VIS). The shape and size of the nanoparticles were analyzed using JEOL-JEM 2100F Field emission gun-transmission electron microscope (FEG-TEM). For TEM the colloidal solution was first sonicated for $15 \mathrm{~min}$, then a drop of it was loaded on a carbon-coated copper grid, allowing the solvent to evaporate under fume hood for $30 \mathrm{~min}$. The functional groups in lichen extract and their possible role in synthesis of AgNPs was studied by Perkin Elmer Spectrum one: fourier transform infrared spectrometer (FTIR) with scan range 450-4000 $\mathrm{cm}^{-1}$.

The antibacterial activity of synthesized AgNPs was studied employing Bauer-Kirby's disk diffusion assay (Bauer 1959, 1966) against gram-positive bacterial strains Bacillus subtilis (MTCC-2390), Staphylococcus aureus (MTCC-6908), Staphylococcus epidermidis (MTCC-6810) and gram-negative bacterial strains Escherichia coli (MTCC-595), Klebsiella pneuomoniae (MTCC-4030), and Pseudomonas aeruginosa (MTCC4727). Gentamicin (10 $\mu \mathrm{g}$ discs, HIMEDIA-SD016) was used as positive control whereas distill water was used as negative control. $10 \mu \mathrm{l}$ of nanoparticle solution was loaded (using sterile micropipette-10 $\mu \mathrm{l}$ ) on sterile discs (HIMEDIA-SD067) which were placed together with Gentamicin discs on nutrient agar plates. The plates were www.tropicalplantresearch.com 
incubated at $37^{\circ} \mathrm{C}$ for $24 \mathrm{~h}$ and the zone of inhibition was measured. Experiments were carried in triplicate and mean values were recorded. Antibacterial activity was assessed by measuring the inhibition zone diameter (IZD) around the discs. Percentage relative inhibition zone diameter (\% RIZD) for different bacterial strains was calculated as:

$$
\% \text { RIZD }=\frac{\text { IZD of the AgNPs }- \text { IZD of negative control }}{\text { IZD of Gentamicin }} \times 100
$$

\section{RESULTS AND DISCUSSION}

The reduction of silver ions into AgNPs by phytochemicals is often detected by a change in color of the reaction mixture which is (Mishra et al. 2019). The colour of the reaction mixture changed to yellowish-brown (Mie et al. 2012, Dasari et al. 2013, Mie et al. 2014a, Din et al. 2015, Paul et al. 2015, Leela \& AnchanaDevi 2017, Khandel et al. 2018, Siddiqi et al. 2018). The UV-Vis spectra peaked at $402 \mathrm{~nm}$ (Fig. 2) due to surface plasmon absorption (SPA) which is within the range of characteristic SPA band range of 400-450 nm usually observed in AgNPs synthesized by lichen/ purified lichen secondary metabolites (Mie et al. 2012, Dasari et al. 2013, Mie et al. 2014a,b, Yildiz et al. 2014, Din et al. 2015, Paul et al. 2015, Çıplak et al. 2017, Leela \& AnchanaDevi 2017, Khandel et al. 2018, Siddiqi et al. 2018).
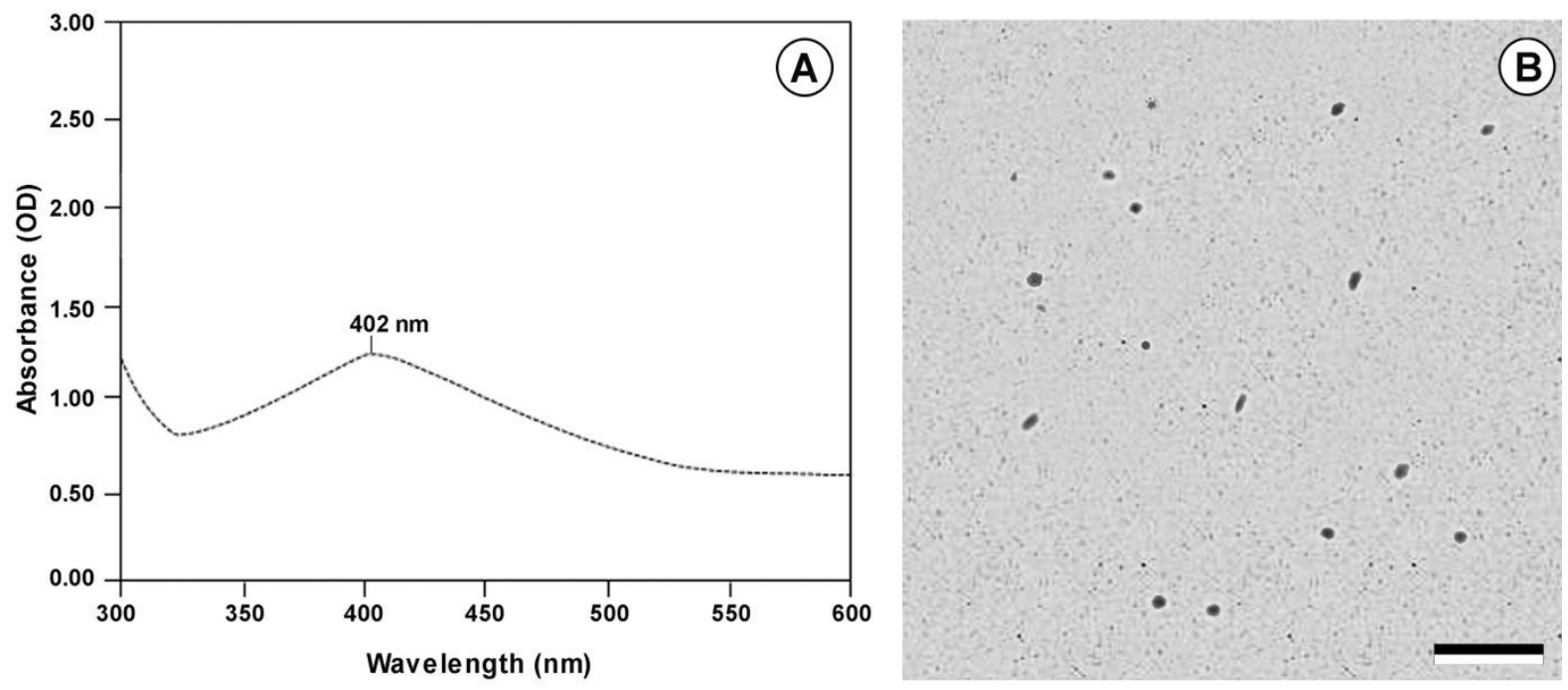

Figure 2. A, UV-Vis absorption spectrum of AgNPs synthesized using the aqueous extract of Cladonia rangiferina (L.) Weber ex F.H. Wigg.; B, TEM image of Cladonia rangiferina-AgNPs obtained after $72 \mathrm{~h}$ of the reduction reaction, (Scale = $1 \mu \mathrm{m})$.

The morphology and size distribution of the synthesized AgNPs determined by TEM analysis showed that the particles were both spherical (Mie et al. 2012, Çıplak et al. 2017, Leela \& Anchana Devi 2017, Khandel et al. 2018, Siddiqi et al. 2018) and of rod shape (Paul et al. 2015) (Fig. 2 C). The particle size of the AgNPs ranged in size from $5 \mathrm{~nm}$ to $40 \mathrm{~nm}$ with an average diameter of $20 \mathrm{~nm}$.

The FTIR analysis of lichen AgNPs showed peaks in the range of $1000-4000 \mathrm{~cm}^{-1}$ which corresponds to many functional groups found in two major secondary metabolites Atranorin and fumarprotocetraric acid of Cladonia rangiferina. The FTIR spectra of AgNPs synthesized from Cladonia rangiferina (L.) Weber ex F.H. Wigg., showed presence of $\mathrm{O}-\mathrm{H}\left(3400 \mathrm{~cm}^{-1}\right), \mathrm{C}-\mathrm{H}\left(2853 \mathrm{~cm}^{-1}\right), \mathrm{C}=\mathrm{O}\left(1742 \mathrm{~cm}^{-1}\right), \mathrm{C}=\mathrm{O}\left(1691 \mathrm{~cm}^{-1}\right), \mathrm{C}=\mathrm{O}$ aldehyde $\left(1651 \mathrm{~cm}^{-1}\right), \mathrm{C}=\mathrm{C}$ vibration $\left(1573 \mathrm{~cm}^{-1}\right), \mathrm{CH}_{2}, \mathrm{CH}_{3}\left(1443 \mathrm{~cm}^{-1}\right)$ and $\mathrm{C}-\mathrm{O}\left(1273 \mathrm{~cm}^{-1}\right)$ suggesting the involvement of polyphenols and other functional groups of multiple organic lichen metabolites in reduction and stabilization of AgNPs (Dasari et al. 2013, Çıplak et al. 2017, Leela \& AnchanaDevi 2017, Khandel et al. 2018, Siddiqi et al. 2018).

The antibacterial activity showed considerable efficiency of Cladonia rangiferina AgNPs against positive control Gentamicin (Fig. 3) (Din et al. 2015, Leela \& AnchanaDevi 2017, Khandel et al. 2018, Siddiqi et al. 2018). The AgNPs showed much greater bactericidal activity against gram-negative bacterial strains than the gram-positive ones (Fig. 3) (Mie 2014a).

\section{CONCLUSION}

The study highlighted the probability of fabricating stable AgNPs from aqueous extracts of lichens such as Cladonia rangiferina (L.) Weber ex F.H. Wigg. from harsh high elevational alpine habitats. The effectiveness of lichen AgNPs was further established in the study with comparatively higher efficiency towards gram-negative 
bacterial strains. The study concluded that the unique secondary metabolites of lichens make them an appropriate reducing and stabilizing agents for synthesis of AgNPs with higher antibacterial efficiency.
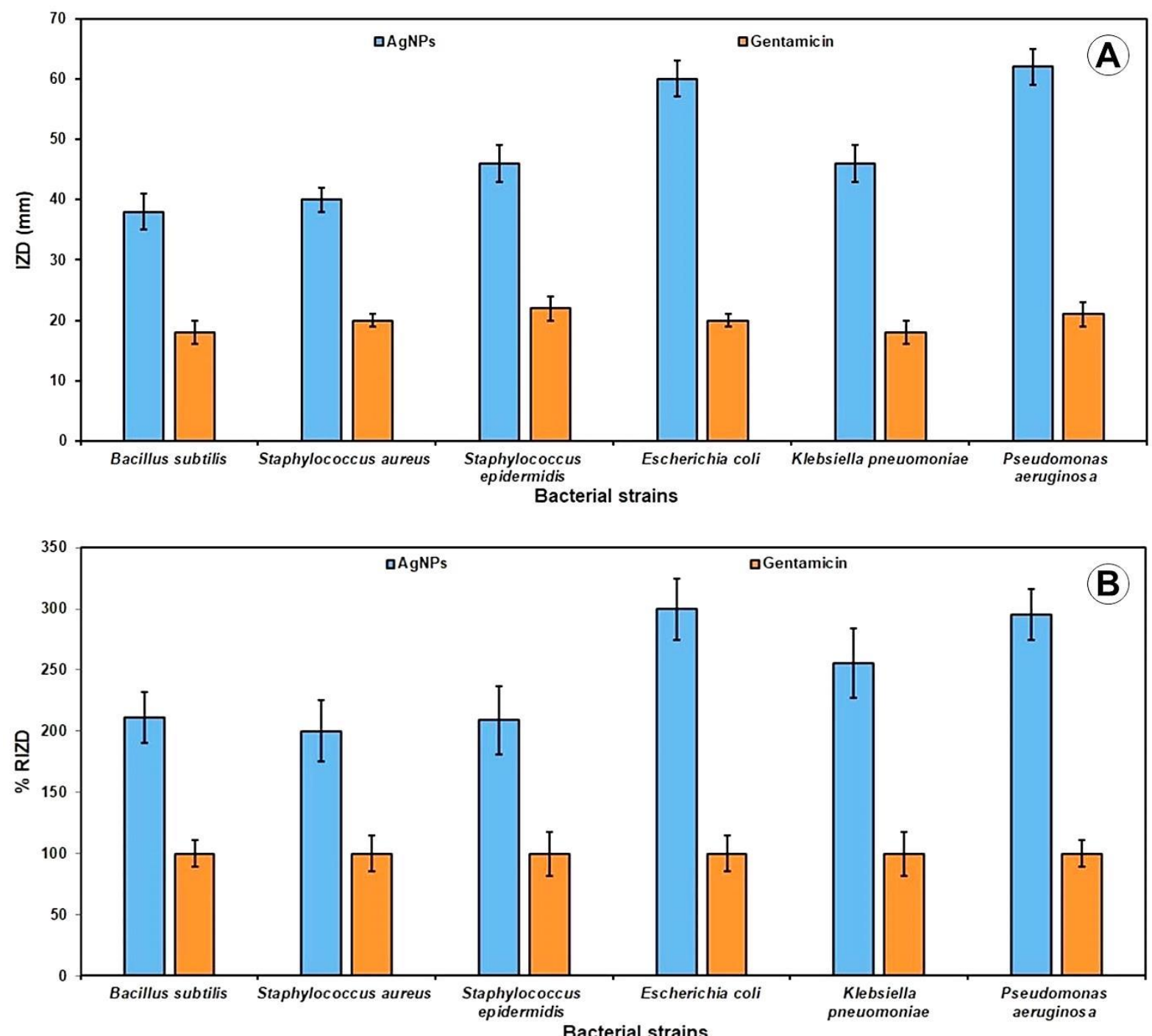

Figure 3. Antibacterial activity of Cladonia rangiferina (L.) Weber ex F.H. Wigg. AgNPs as A, IZD, and B, \%RIZD on selected gram-negative and gram-positive bacterial strains.

\section{ACKNOWLEDGEMENT}

Authors are thankful to the Head, Centre of Advanced Study in Botany, Institute of Science, Banaras Hindu University, Varanasi-221005, Uttar Pradesh, India, for providing necessary laboratory facilities.

\section{REFERENCES}

Alvarez-Ordóñez A, Coughlan LM, Briandet R \& Cotter PD (2019) Biofilms in food processing environments: challenges and opportunities. Annual Review of Food Science and Technology 10: 173-195.

Bauer AW, Kirby WMM, Sherris JC \& Turck M (1966) Antibiotic susceptibility testing by a standardized single disk method. American Journal of Clinical Pathology 45: 493-496.

Bauer AW, Perry DM \& Kirby WM (1959) Single-disk antibiotic-sensitivity testing of staphylococci: An analysis of technique and results. AMA Archives of Internal Medicine 104: 208-216.

Çıplak Z, Gökalp C, Getiren B, Yıldız A \& Yıldız N (2018) Catalytic performance of Ag, Au and Ag-Au nanoparticles synthesized by lichen extract. Green Processing and Synthesis 7(5): 433-440.

Dasari S, Suresh KA, Rajesh M, Siva Reddy CS, Hemalatha CS, Wudayagiri R \& Valluru L (2013) Biosynthesis, Characterization, Antibacterial and Antioxidant Activity of Silver Nanoparticles Produced by Lichens. Journal of Bionanoscience 7: 237-244.

Din LB, Mie R, Samsudin MW, Ahmad A \& Ibrahim N (2015) Biomimetic synthesis of silver nanoparticles using the lichen Ramalina dumeticola and the antibacterial activity. Malaysian Journal of Analytical Sciences 19: 369-376. 
Dixit S \& Tripathi A (2019) A review on biosynthesis, characterization and antimicrobial effect of silver nanoparticles of Moringa olifera (MO-AgNPs). Journal of Pharmaceutical Sciences and Research 11: 1937-1943.

Elix J \& Stocker-Wörgötter E (2008) Biochemistry and secondary metabolites. In: Nash T III (ed) Lichen Biology. Cambridge University Press, Cambridge, pp. 104-133.

Husen A \& Siddiqi KS (2014) Phytosynthesis of nanoparticles: concept, controversy and application. Nanoscale Research Letters 9: 229.

Husen A (2017) Gold nanoparticles from plant system: synthesis, characterization and their application. In: Ghorbanpour M, Manika K \& Varma A (eds) Nanoscience and plant-soil systems, Vol 48. Springer, Cham, pp. 455-479.

Hussain I, Singh A, Singh H, Singh SC \& Singh NB (2015) Physiological response of broccoli exposed to RuO2 nanoparticle. Tropical Plant Research 2(3): 246-252.

Khandel P, Shahi SK, Kanwar L, Yadaw RK \& Soni DK (2018) Biochemical profiling of microbes inhibiting Silver nanoparticles using symbiotic organisms. International Journal of Nano Dimension 9: 273-285.

Korbekandi H, Iravani S \& Abbasi S (2009) Production of nanoparticles using organisms. Critical Reviews in Biotechnology 29: 279-306.

Leela K \& AnchanaDevi C (2017) A study on the applications of silver nanoparticle synthesized using the aqueous extract and the purified secondary metabolites of lichen Parmelia perlata. International Journal of Pharmaceutical Science Invention 6: 42-59.

Mie R, Din LB, Samsudin MW \& Ahmad A (2014b) Secondary metabolite isolated from Ramalina dumeticola and its application for silver nanoparticles production. AIP Conference Proceedings 1614: 213-217.

Mie R, Samsudin MW, Din LB \& Ahmad A (2012) Green synthesis of silver nanoparticles using two lichens species: Parmotrema praesorediosum and Ramalina dumeticola. Applied Mechanics and Materials 229: 256-259.

Mie R, Samsudin MW, Din LB, Ahmad A, Ibrahim N \& Adnan SNA (2014a) Synthesis of silver nanoparticles with antibacterial activity using the lichen Parmotrema praesorediosum. International Journal of Nanomedicine 9: 121-127.

Mishra VK, Husen A, Rahman QI, Iqbal M, Sohrab SS \& Yassin MO (2019) Plant-Based Fabrication of Silver Nanoparticles and Their Application. In: Husen A \& Iqbal M (eds) Nanomaterials and Plant Potential. Springer, Cham, pp. 135-175.

Paul S, Singh AR \& Sasikumar CS (2015) Green synthesis of bio-silver nanoparticles by Parmelia perlata, Ganoderma lucidum and Phellinus igniarius \& their fields of application. Indian Journal of Research in Pharmacy and Biotechnology 3: 100-110.

Qayyum H, Ali R, Rehman ZU, Ullah S, Shafique B, Dogar AH, Shah A \& Qayyum A (2019) Synthesis of silver and gold nanoparticles by pulsed laser ablation for nanoparticle enhanced laser-induced breakdown spectroscopy. Journal of Laser Applications 31: 022014.

Rai H, Khare R, Upreti DK \& Ahti T (2014b) Terricolous lichens of India: taxonomic keys and description. In: Rai H \& Upreti DK (eds) Terricolous lichens in India Morphotaxonomic studies, Vol 2. Springer, New York, pp. 17-294.

Rai H, Khare R, Upreti DK \& Nayaka S (2014a) Terricolous lichens of India: an introduction to field collection and taxonomic investigations. In: Terricolous lichens in India: Morphotaxonomic studies, Vol 2. Springer, New York, pp. 1-16.

Ranković B (2015) Lichen Secondary Metabolites: Bioactive Properties and Pharmaceutical Potential. Springer International Publishing, Cham, 202 p.

Rodrigues AG, de Oliveira Gonçalves PJR, Ottoni CA, de Cássia Ruiz R, Morgano MA, de Araújo WL, de Melo IS \& De Souza AO (2019) Functional textiles impregnated with biogenic silver nanoparticles from Bionectria ochroleuca and its antimicrobial activity. Biomedical Microdevices 21(3): 56.

Roohizadeh G, Majd A \& Arbabian S (2015) The effect of sodium silicate and silica nanoparticles on seed germination and some of growth indices in the Vicia faba L. Tropical Plant Research 2(2): 85-89.

Shekhawat MS, Ravindran CP \& Manokari M (2014) A Biomimetic Approach towards Synthesis of Zinc oxide Nanoparticles using Hybanthus enneaspermus (L.) F. Muell. Tropical Plant Research 1(2): 55-59.

Siddiqi KS, Rashid M, Rahman A, Tajuddin, Husen A \& Rehman S (2018) Biogenic fabrication and characterization of silver nanoparticles using aqueous-ethanolic extract of lichen (Usnea longissima) and their antimicrobial activity. Biomaterials Research 22: 23-31. 
Singh A, Singh NB, Hussain I, Singh H \& Yadav V (2017) Synthesis and characterization of copper oxide nanoparticles and its impact on germination of Vigna radiata (L.) R. Wilczek. Tropical Plant Research 4(2): $246-253$.

Singh VK \& Singh AK (2019) Role of microbially synthesized nanoparticles in sustainable agriculture and environmental management. In: Kumar A, Singh AK \& Chaudhary KK (eds) Role of Plant Growth Promoting Microorganisms in Sustainable Agriculture and Nanotechnology. Woodhead Publishing, pp. 5573.

Tryfon P, Antonoglou O, Vourlias G, Mourdikoudis S, Menkissoglu-Spiroudi U \& Dendrinou-Samara C (2019) Tailoring Ca-based nanoparticles by polyol process for use as nematicidals and $\mathrm{pH}$ adjusters in agriculture. ACS Applied Nano Materials 2: 3870-3881.

Yadav A, Kon K, Kratosova G, Duran N, Ingle AP \& Rai M (2015) Fungi as an efficient mycosystem for the synthesis of metal nanoparticles: progress and key aspects of research. Biotechnology Letters 37: 20992120.

Yazdian-Robati R, Arab A, Ramezani M, Rafatpanah H, Bahreyni A, Nabavinia MS, Abnous K \& Taghdisi SM (2019) Smart aptamer-modified calcium carbonate nanoparticles for controlled release and targeted delivery of epirubicin and melittin into cancer cells in vitro and in vivo. Drug Development and Industrial Pharmacy 45: 603-610.

Yıldız N, Ateş Ç, Yılmaz M, Demir D, Yıldız A \& Çalımlı A (2014) Investigation of lichen based green synthesis of silver nanoparticles with response surface methodology. Green Processing and Synthesis 3: $259-270$. 